\title{
Bureaucratic politics and the prevention of leaks in the European Commission
}

\author{
Ronny Patz, LMU Munich
}

Abstract: The European Commission, much like other executives and public administrations in Western Democracies, is frequently faced with leaks. Even though executive leaders often criticize this practice as unwanted breach of confidentiality and secrecy, research has shown that leak prevention is usually not taken seriously beyond public complaints. This paper analyses the phenomenon of leaking in the European Commission and the efforts the Commission makes to prevent leaks from its own ranks. It finds that leaking and leak prevention are regularly discussed at the highest level of the Commission. However, a survey with leak recipients suggest that leaks seem so widely distributed and frequent at various stages of internal decision-making that the existing prevention efforts seem ineffective. Analysing the rules and practices of leak prevention, the paper shows that, while there are anti-leak rules in place, there have been very few cases in which Commission leakers have been administratively sanctioned. The explanation for these observations builds on the argument that leaking is part of regular bureaucratic politics and that leak prevention therefore is not meant to be effective, except for a few important cases.

Paper presented for the workshop "Secret Politics and Politics of Secrecy in Europe" (Part II), Panel "Secrecy, Oversight and Accountability”. 2-3 March 2017, IBZ, Munich.

Please cite with caution as this is a draft version (28 February 2017). Comments are welcome under ronny.patz@gsi.lmu.de. 


\section{Introduction}

"By virtue of their unvarnished nature, leaks have evolved into the realest of facts. This epistemological status has been fortified in recent years with a series of spectacular leaks that successfully reframed official narratives as grand fictions." (Herrman 2017)

A few spectacular megaleaks - from the Wikileaks' 'Cablegate' to a series of leaks on the EU-US Transatlantic Trade and Investment Partnership (TTIP) - have shifted global attention to matters of secrecy, transparency and the role of whistleblowing. However, leaks are a phenomenon that is much more mundane than what the mediatised attention to the exceptional nature of leaks such as ones by Edward Snowden or Chelsea Manning suggests (Reich and Barnoy 2016). Notably, short after the recent US presidential election campaign, during which another mass leak by Wikileaks in the form of emails of the Democratic National Party dominated the news, the new Trump administration was quickly faced with, and complained about, a series of 'regular' political leaks (Hermann 2017).

Researchers have studied leaking of this more common type in various Western political systems, including in the USA (Prémon 2010, 2012; Pozen 2013; Alaimo 2016), the Netherlands (Bovens, Geveke and de Vries 1995; de Jong and de Vries 2007), Israel (Reich 2008), Australia (Flynn 2006, 2011), Germany (Spörer-Wagner and Marcinkowski 2010), and the European Union (Patz 2014, 2016; Herrmann 2015). Disciplinary perspectives on leaking range from law (Pozen 2013) and journalism studies (Reich 2008; Reich and Barnov 2016, Flynn 2006) to political science and public administration (Bovens, Geveke and de Vries 1995; de Jong and de Vries 2007; Spörer-Wagner and Marcinkowski 2010; Prémon 2012; Patz 2014), although many contributions on political leaking go across disciplinary boundaries.

The key question for this paper is why the prevention of regular leaks by public administrations seems so unsuccessful. The argument made to answer this question follows a political science and public administration conceptualization of "leaking [as] an instrument in the political and administrative struggle for power" (Bovens, Geveke and de Vries 1995: 23) and as an influence strategy among others in bureaucratic politics (Prémon 2010: 22-25). Previous observations made in the study of leaking and leak prevention in US politics indicate "[that] most components of the executive branch have never prioritized criminal, civil or administrative enforcement against leakers; that a nuanced set of informal social controls has come to supplement, and nearly supplant, the formal disciplinary scheme; 
[...] [and] that the executive's toleration of these disclosures is a rational, powerenhancing strategy [...], a feature, not a bug, of the system" (Pozen 2013: 515).

Using these observations as key empirical conjectures for the further study of this phenomenon, I will analyse the dynamics of leaking and the politics of leak prevention in the European Commission. The findings of this case study contribute to a comparative understanding of leaking in different political systems. The insights gained will also add to the literature on the administrative and political dynamics inside the Commission as the core executive of the European Union (Hartlapp et al. 2013; Kassim et al. 2013; Wille 2013 Goetz and Patz 2016; Hustedt and Seyfried 2016). Demonstrating that Pozen's observations can be transferred to the EU, the article gives rise to the argument that, in more open political and administrative systems, rules on secrecy and confidentiality are not necessarily meant to be fully effective beyond (inter)national security concerns and beyond areas of central political interest to those in power. Where we find confidentiality enforced in Western political systems, this should be selective and limited to instances where the strategic interests of political leadership are concerned. This enriches discussions on the politics and regulation of secrecy, confidentiality, and lack of transparency in the EU (Curtin 2014; Galloway 2014; Abazi 2015; Rosén 2015; Hillebrandt and Novak 2016) and the emerging debate on secrecy in Europe.

The paper will, in a first step, present the conceptual and empirical state of the art on leaking as bureaucratic politics to underpin the study's conjectures theoretically. In the following section, the key dynamics of leaking in the European Commission are presented based on the systematic analysis of meeting minutes of the College of Commissioners in the period 200615. This is supplemented with additional evidence, including an email survey with 40 recipients of leaked drafts of the 2011 European Commission proposal for the reform of the EU's Common Fisheries Policy (CFP). This empirical material allows for an understanding of Commission leaking from an administrative and from an outside perspective. The next section will then summarise the formal rules and measures put in place in the Commission to prevent leaking, before showing how few disciplinary sanctions there have been from 2006-15. These findings based on reports of the Commission's Investigation and Disciplinary Office (IDOC) are contrasted with the College debates related to leaks during the same period. I can demonstrate how measures of limiting leaks through (a) explicit sanctions and through (b) procedural adaptations, such as shortening consultation periods and limiting the circle of those involved in drafting Commission policy, are used selectively to balance strategic 
interests with a smooth functioning of the Commission as a complex bureaucracy. In the conclusions, these observations are reconsidered with a view to the broader debates that this articles contributes to.

\section{Leaking and bureaucratic politics: theoretical and empirical perspectives}

Despite the fact that "[n]o bureaucracy is comfortable with unauthorized disclosures" because it exposes real or constructed "organizational deviance" (Flynn 2006: 269), leaks are a relatively common phenomenon in Western bureaucratic politics. Yet, estimating the real amount of leaks in a given political system is challenging (Reich 2008). Previous research found that between $2.3 \%$ and $20 \%$ of all news items in the US are based on leaks (Reich and Barnoy 2016: 888). While the difference between these figures simply may be the result of methodological choices, differences in the estimation of leaks can also be the result of various definitions and conceptualizations of what constitutes a 'leak'. Bovens, Geveke and de Vries (1995: 19) distinguish leaking from whistleblowing by arguing that the former concerns "any type of information" where the latter concerns only revelations of abuse. They then define leaking as "making confidential information public by office-holders on the basis of anonymity", explicitly excluding leaking that does not involve the press. Alternative definitions also refer to leaking as a disclosure to the press that can either be authorized at higher level or unauthorized (Pozen 2013: 522). Others consider only unauthorized disclosures that are meant to disrupt decision-making procedures to be leaks (cf. Prémon 2010: 15-16). I follow a broad conceptualization where leaking is seen as a "violation of confidentiality (1), done intentionally to further one of [sic] more interests (2), involves information exchange (3) and is done anonymously (4)" (de Jong and de Vries 2007: 217).

Typologies of leaks relate to different intentions of the leaker. It has been argued that the most relevant type of leaks for the study of bureaucratic politics are deliberate leaks made out of institutional interest, i.e. those meant to support the leaker's institutional and policy preferences (Bovens, Geveke and de Vries 1995: 24). Those leaks, authorized or not, may be used to either mobilize the general public or interest groups for, or against, a certain cause for which a final decision has not been made. Alternatively, they can be used in an antagonizing tactic, either to discredit an opponent by making an unpopular position public, or by revealing an early positioning of major actors to lock in that position against future revisions (ibid.: 2628). While leaking usually is referred to where said leaks are directed at the press, and through the press to the public at large, the argument made above also holds for leaks that are 
given to interest groups. For the purpose of this study, I therefore include leaking to these actors.

Before reflecting on some of the empirical observations made by those who have previously studied leaks, it is worth taking one step back and to consider leaks in their wider context. Leaks have always been an epiphenomenon of the struggles between secrecy and transparency, between strategic political control and procedural or substantive openness. On one side, there is the "hierarchist worldview" on information where the rules governing access to information are "dominated by the needs of established authority" (Hood 2010, 999), on the other side there is a more "egalitarian" world view in which transparency is seen "as a human right" and as an instrument for "effective accountability" (Hood 2010, 1001). The megaleaks of the past years have elevated this debate to one held at a societal scale. In the early $21^{\text {st }}$ century, questions of government secrecy, individual privacy and the public's right to know are increasingly interconnected, and the positions taken align rather well with the hierarchist and egalitarian worldviews. However, studying leaking as a politicaladministrative strategy in political games between government agencies or different departments of public administrations requires a more narrow view. Transparency-related 'worldviews' may only be one of several explaining factors for leaking, for example when officials consider that a certain topic or information deserves a broader public debate. In most instances, these worldviews may play are role, but leaks driven by policy conflicts, interagency resource conflicts or bureaucratic career advancement considerations are likely to be the more convincing explanations for why leaking happens in the empirical reality of bureaucratic politics. There are a range of empirical findings that underpin these assumptions:

First, leaking occurs in all major policy areas (de Jong and de Vries 2007), not just in fields where secrecy is considered highest, such as national security. But even in this field there are significant leaks: In the US case, "publication of classified information" was found to be "a routine daily occurrence“ in the early 1980s (Willard Report 1982), something the security agencies deplored in the Willard Report and have always disliked. Yet, the notion that leaks are necessarily negative is contested in the literature (Bovens, Geveke and de Vries 1995; de Jong and de Vries 2007). Where they create public attention and debate in political or administrative negotiations, these debates mostly reflect already existing conflicts among those actors who are negotiating (Spörer-Wagner and Marcinkowski 2010). Thus, there is usually anticipation for both the leak and the resulting debate among pubic officials. It is therefore not surprising to find that leaks have not been found, for example, to be a key factor 
shaping various US President's foreign policy in substance. Still, they have clearly influenced the dynamics of decision-making in this field (Prémon 2010: 292-293). Preserving confidentiality thus seems much more about playing "time games" (Howlett and Goetz 2014: 478) than about the fact that early information leaks have a direct policy influence. Variation in timing of leaks can therefore reveal something about the political and administrative system in which the leak happened or indicate the political dynamics behind particular decision-making processes (Patz 2016). This is why leaks are a valuable source for researching bureaucratic politics and public policy-making (cf. Michael 2015).

Second, research on leaks has attempted to explain the social dynamics of leaking, which is important to understand whether and when leaks are to be expected. Some argue that leaks are mainly coming from senior officials, those with good access to information, political interests of their own, and regular contact with outside actors (Reich 2008; Pozen 2013: 529-30). However, recent studies suggest that there seems to be a trend that leaks are induced not by higher echelons but increasingly coming from less senior officials. Technology and the ability of junior officials to more easily access and copy politically sensitive or even confidential information could be one of the drivers of this change (Reich and Barnoy 2016). Qualitative studies indicate, however, that political appointees leaks as much as regular civil servants (Alaimo 2016). That being said, journalists report to prefer leaks from the middle ranks because these are seen to add to the political spin coming from higher levels and political appointees (Flynn 2006). Interestingly, and despite the advances in technology that allow for easier leaking, leaks to journalists have remained mainly an oral practice (Reich and Barnoy 2016). This requires close contact between leak sender and receiver, and may explain why leaking happens in relatively stable networks based on regular contact between policy-makers and journalists or interest groups (de Jong and de Vries 2007; Patz 2014). And because leaking happens in those policy networks, oral leaking is usually complemented with leaking of policy drafts as these are required for interest groups to decide on their influence strategies (Patz 2014). So, there is good reason to believe that leaks happen in oral and written form.

As regards to the prevention of leaks, prosecution against leakers has not been found to be effective, mainly because leaking is so institutionalized. In reaction to this realisation, it has been suggested in the 2000s in the Netherlands to reduce the number of secrets altogether. In combination with clearer classification systems, it was expected that this could result in broader awareness about which information is really meant to be confidential (de Jong and de Vries 2007: 224). However, Curtin (2014) argues, and shows for the case of the EU, that such 
an approach - clarifying secrecy through classification - can also lead to a system of overclassification. Still, in the US, where there are large amounts of classified information and thousands of leaks thereof, there have been only "roughly a dozen criminal prosecutions" for leaking national security related leaks (Pozen 2013: 534). And while there is little to no data on administrative actions and on the amount reprimands against leakers, the number of publicly known leak-relatedcases of administrative sanctions in the US is also low (Pozen 2013: 540).

In his analysis, Pozen deconstructs previously existing arguments that these observations relate to the lack of capacity of the government or agencies to detect and sanction leakers. Instead, he shows how "leaking is a heterogeneous activity that occurs in a repeat-play environment“" (Pozen 2013: 546). Thus, even though there are public complaints by political leaders about leaks, they know that at a later stage they will make use of the practice, and that hard prosecution in one case might undermine their own credibility when they do not go after leaks that are in their own interest. Especially if leaking is happening from the top, political leadership has little incentive to punish itself with increased supervision. In addition, leaks are also means "through which the executive branch speaks to itself" (Pozen 2013: 577) and to those responsible for oversight (Pozen 2013: 582). Faced with a complex bureaucracy, leaks can make senior officials or parliamentary committees aware of what is going on within their agencies. Through leaks, they can know when their intervention in bureaucratic politics with high salience may be required. Thus "a policy of permissive neglect towards leaking may not only be efficiency-enhancing relative to the baseline of colossal official secrecy [because] overclassification threatens to stifle important decisional inputs and cause policy sclerosis“ (Pozen 2013: 577), but simply because leaking is part of regularly public policy-making.

In the following section, I want to test whether the observations made in previous research with regard to a lack of enforcement of anti-leaking rules can be confirmed for the case of the European Commission. Six conjectured are operationalised and then checked against empirical evidence.

Conjecture 1.1: $\quad$ Leaks are a frequent phenomenon in the European Commission and the Commission leadership will regularly complain about them.

Conjecture 1.2: Technological advancement has increased the frequency of leaks and the salience of leaking as an issue for the Commission leadership.

Prior research has used various measures to study the frequency of leaks, such as analysing news report, but these and other approaches all have methodological flaws (Reich 2008). I 
operationalise the frequency of leaks by studying how often the Commission leadership has dealt with leaks at the highest level (in the College) in the past decade and compare this with previous research that has referred to leaks from the Commission.

Conjecture 2: $\quad$ Leaking is used strategically to influence negotiations between Commission departments.

The motivation for leaking is even more difficult to measure than the frequency. However, if leaks represent bureaucratic politics and not ideological statements against secrecy, then one should find leaks to occur when they have the highest potential to influence Commission policy formulation and when leakers have the lowest risk of being identified. In the Commission, this should be as soon as various departments are being consulted on draft proposals. I will demonstrate the plausibility of this conjecture through a survey with stakeholders who have received leaks from the Commission.

Conjecture 3.1: There are administrative rules and procedures in place to discourage leaking, but these rules will rarely be enforced for leaks most typical for bureaucratic politics.

Conjecture 3.2: $\quad$ Rules and measures to prevent leaks have been adapted to reflect the technological possibilities in the age of megaleaks.

Identifying administrative rules is straightforward, whereas identifying more detailed measures is challenging. This information needs to be requested from central services responsible for formulating and enforcing anti-leak rules, who should also be aware of changes over time. Internal reports on enforcement can give indications about the number of cases and the changes over time.

Conjecture 4: Formal measures against leaking will be supplemented by measures of social and temporal control to allow the Commission leadership strategic influence on the dynamics of leaking.

Measuring social and temporal control of leaking beyond formal rules requires qualitative data. I use Commission College meeting minutes, Commission emails published after freedom of information requests and insights from an interview with two Commission officials to identify what these measures are and how they are strategically used to influence leak dynamics. 
In the following section, I first present empirical evidence relating to Conjectures 1.1, 1.2 and 2 before discussing the measures and strategies for leak prevention relating to Conjectures 3.1, 3.2 and 4 in the following section.

\section{The dynamics of leaking in the European Commission}

The European Commission is a complex public administration with separation between the political bureaucracy comprised of the Commission President, several vice-presidents and individual Commissioners (all 28 together form 'the College'), including their respective cabinets, and the relatively independent line departments called 'directorates-general' (and 'services'), centrally coordinated by the Secretariat-General of the Commission (see Hartlapp et al. 2013 for details). Most importantly, it possesses the monopoly on proposing new EU legislation, including the monopoly to propose the budget (Goetz and Patz 2016), and also exercises a wide range of executive and supervisory functions. The latter encompasses the right to decide on significant fines for member states, and economic entities within member states, for breaking EU competition rules. These wide-ranging competencies, paired with a vertically and horizontally differentiated administrative structure with many possible internal conflict lines, paired with the social reality of the 'Brussels bubble' with close contacts between policy-makers, journalists and interest groups provide a fertile breeding ground for leaks. Thus, not only the "United States government leaks like a sieve" (Pozen 2013: 513), but

"many observers agree that the Commission has been 'leaking like a sieve', and that journalists and lobbyists have had easy access to documents of the institutions." (Grønbech-Jensen 1998: 191)

There are strong indications that the European Commission has been particularly leaky for a long time. In the early 1990s, for example, British officials in the European Communities considered that the European institutions were much leakier than the British foreign ministry, Whitehall. In their view, leaks were "elevated almost to the status of accepted operating procedure" in the EU. The reason for such an "operating procedure" seemed to be that EC officials needed to be open to the outside world because "the Community's effectiveness depend[ed] as much on engineering consent as on designing technically efficient regulations." Secrecy was possible to ensure the technical regulation, but transparency through leaks ensured public and interest group support (Christoph 1993, 528). Others argued that the difference between the two cultures was the difference of having the Official Secrets Act in 
the UK, with no equivalent in the Commission (Cini 1997, 122). Both observations were made before the EU introduced detailed rules on transparency and secrecy from 2001 onwards, Regulation 1049/2001 on access to EU documents on the one side and wide-ranging rules on EU Classified Information on the other (Galloway 2014). Nevertheless, the evidence below indicates that leaking still is a common phenomenon in the European Commission.

After the 2015 work programme of the newly elected European Commission under JeanClaude Juncker got leaked before it was officially presented to the public in 2014 (Corporate Europe Observatory 2014), the Commission leadership was quite unhappy, as expressed in the speech by Vice-President Timmermans when he presented the final work programme to the European Parliament. However, this was not the first time that the Commission's leadership had to deal with leaks at the highest level. During the past decade (2006-2015), the public minutes of the Commission's weekly College meetings report 12 instances at which a leak coming from the Commission was explicitly discussed (see Figure 1 below). Leaks were discussed in two further instances, but these cases did not relate to leaks coming from the Commission or from situations with direct involvement of the Commission. ${ }^{1}$ Interestingly, the WikiLeaks leaks in 2010 and the NSA leaks in 2013 did not lead to specific discussions in the regular College meetings and they did also not lead to more debate about leaks in the College. Overall, and while the topic comes up regularly, the number of cases is still low, except for 2012 with seven meetings discussing some sort of leak. This does not allow confirming Conjecture 1 regarding the high frequency of leaks, but where they matter they still become an issue that the highest level complains about.

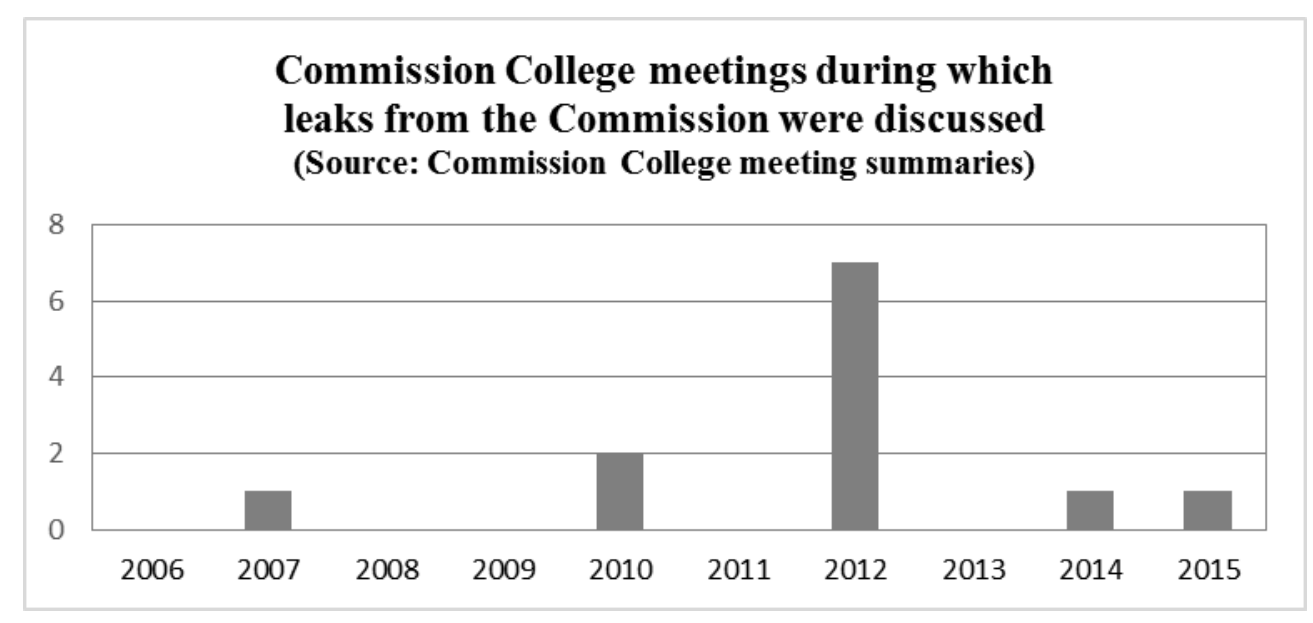

Figure 1. Number of weekly Commission College meetings during which leaks were discussed.

\footnotetext{
${ }^{1}$ In one further case, the leakage of oil from a capsized ship was discussed, i.e. not an information leak.
} 
The leaks discussed in the College in the past decade related to various issues and are mostly incidental to certain policy debates. Only in a few cases are the leaks discussed in the context of wider working methods of the Commission. The substantive patterns of the leaks reveal various types of leaks: One third of the cases concerned issues that are sensitive to certain member states, such as progress reports on Bulgaria and Romania (2007), recommendations of the Commission to member states on their economic policies in the context of the European Semester (2012) or reports on Cyprus (2012) and on Greece (2012). One third of cases concerned more general policy issues such as carbon leakage measures (2010), banking supervision (2012), the preparation of the EU budget (2012) or gender equality on company boards (2012). Two discussions related to leaking in competition cases $(2010,2012)$ and the other two to the leaks in the early days of the Juncker Commission $(2014,2015)$. None of these cases points to any substantive changes with regard to the evolution of leaking in the Commission. The particular spike in cases in 2012 is rather related to the politically sensitive nature of anti-crisis measures than to trends related to technological changes or changes after the megaleaks. This does not give support to Conjecture 1.2 that the frequency of leaks is increasing. However, the limitation of the data is that it only covers those discussions held formally in the College and reported in the public minutes. It is therefore possible that leaks have been a much more frequent topic at the level of the weekly meetings of Chefs de Cabinets, or during the meetings of the Directors-General of the Commission for which no public record is available. Still, the instances reported in the public minutes show that these matters do indeed reach the level of the College when they are important, and they also get reported. There is therefore good reason to believe that the data here gives a valid representation of the most salient leaks.

The open question for this section is whether one can find confirmation on Conjecture 2, i.e. that leaking is mainly a matter of bureaucratic politics used to influence interdepartmental negotiations. The majority of leaks reported in the College meetings do not necessarily fall into this category, as many of these leaks have happened in the few days before the respective College meeting or before the respective decisions were officially made public. Leaks of this kind rather point to conflicts at the level of the College and their cabinets, very visible for example during the adoption of gender equality rules for company boards in 2012 (European Commission 2012a: 19).

However, whereas the College seems to discuss mainly "late" leaks, those meant to influence College decision making, a key finding from previous EU studies is that leaking from the 
Commission seems most likely after the start of the so-called 'interservice consultation' (Patz 2016). When other departments are consulted on a proposal drafted within the Commission's lead directorate-general (for details on the internal decision-making dynamics inside the Commission see Hartlapp et al. 2013), bureaucratic politics take over whenever the file contains controversial matters. Leaking at this stage can be used to mobilise support or opposition, strengthening or weakening lead DGs and Commissioners responsible. At the interservice consultation [ISC] stage, both key issues and many details are not yet set in stone, so generating the right kind of lobbying or raising public attention to certain issues can be used as a tactic to shape the outcome of internal decision-making inside the Commission. In an email exchange between then Secretary-General of the Commission, Catherine Day, and the DG responsible for health (DG SANCO), the SG suggested delaying an interservice consultation on a tobacco directive until after an upcoming European Council because "this [was] a text that might well leak even from ISC" and the Commission leadership was "keen to avoid too much controversy" (European Commission 2012b).

To better understand the dynamics of leaking from the EU Commission after the start of interservice consultation, I conducted an email and telephone survey with (potential) recipients of leaks of draft versions of the European Commission's 2011 reform proposal for the EU's Common Fisheries Policy. After establishing that there had been no authorised disclosure from the Commission to third parties as a result of a freedom of information request or as part of the formal consultation of stakeholders in consultative committees for fisheries policy, the survey was conducted first with the offices of MEPs represented in the EU's Fisheries Committee in 2011 (as a pre-test) and with individuals from interest groups and national governments who had participated in meetings of 10 consultative committees in the field of EU fisheries policy during 2009 and 2010. Respondents were asked about their access to leaked versions of the draft as well as the timing and sources of the leak. For the details of the methodology, including the identification of the base population and the questionnaire design, as well as for the results of the full survey including non- and negative responses see Patz (2014).

For the purpose of this paper, I present insights from those respondents of the pre-test and main survey who reported that they had indeed received at least one leaked version of the Commission's draft before the legislative proposal was officially published in July 2011. In total, 40 individual replies provide direct information on the dynamics of the leak: 3 out of 10 MEPs' offices (30\%) contacted for the pre-test and 37 out of 65 stakeholders $(55.9 \%)$ who 
replied directly to the survey questionnaire (out of 367 individuals contacted via email from a population of 1144 individual stakeholders identified) indicated that they had received a leak. In the following, I present the replies to the four questions asked to respondents who indicated that they had received a leak. The questions covered (1) the number of leaked versions received, (2) the timing of the leak(s), (3) the sources of the leak(s) and (4) whether respondents forwarded the leaks they received to others. Table 1 below provides a first overview.

\begin{tabular}{|l|c|c|c|c|c|}
\hline $\begin{array}{l}\text { Background of } \\
\text { individual respondents }\end{array}$ & $\begin{array}{c}\text { Total } \\
\text { Nof cases } \\
\text { receiving at } \\
\text { least one leak }\end{array}$ & $\begin{array}{c}\text { Received } \\
\text { leak directly } \\
\text { from the } \\
\text { COM }\end{array}$ & $\begin{array}{c}\text { Received } \\
\text { more than } \\
\text { one leaked } \\
\text { version }\end{array}$ & $\begin{array}{c}\text { Leak received } \\
\text { in April or } \\
\text { May 2011 } \\
\text { (during ISC) }\end{array}$ & $\begin{array}{c}\text { Forwarded } \\
\text { the leak(s) } \\
\text { received to } \\
\text { others }\end{array}$ \\
\hline $\begin{array}{l}\text { Government or Public } \\
\text { Body }\end{array}$ & 5 & 0 & 3 & 1 & 3 \\
\hline $\begin{array}{l}\text { EU-level interest group } \\
\text { (incl. federations, } \\
\text { coalitions) }\end{array}$ & 10 & 3 & 8 & 8 & 7 \\
\hline $\begin{array}{l}\text { National-level } \\
\text { interest group }\end{array}$ & 15 & 0 & 8 & 9 & 13 \\
\hline $\begin{array}{l}\text { Regional Advisory } \\
\text { Committee (RAC) }\end{array}$ & 3 & 0 & 1 & 2 & 2 \\
\hline $\begin{array}{l}\text { Office of a Member of } \\
\text { the European Parliament }\end{array}$ & 3 & 0 & 0 & 0 & 0 \\
\hline $\begin{array}{l}\text { Others (Academia, non- } \\
\text { lobby companies) }\end{array}$ & 4 & 0 & 2 & 0 & 2 \\
\hline \multicolumn{1}{|c|}{ Total } & $\mathbf{4 0}$ & $\mathbf{3}$ & $\mathbf{2 2}$ & $\mathbf{2 0}$ & $\mathbf{2}$ \\
\hline
\end{tabular}

Table 1. Dynamics of a leak of the Commission draft proposal for the reform of the EU's Common Fisheries Policy ahead of the formal publication in mid-July 2011 (survey conducted with stakeholders between December 2011 and March 2012; only respondents reporting that they had received a leak and that provided valid answers included here)

There are four key findings emerging from the dynamics of leaking observed in this case: first, very few of actors who replied to the survey received the leak directly from the Commission and those who did report that they did receive one were all based in Brussels. Due to non-response in the survey, it is difficult to know how many other interest groups did receive the leak directly, but the data clearly shows that policy leaks travel fast and wide within the respective policy communities (also underlined by the amount of leak forwarding observed). For an official who leaks it is therefore pretty easy to go on undetected because there is always plausible deniability as the leak may have come from many directions. It is also clear that many who received a leak did so in the first weeks after the start of the interservice consultation, i.e. earlier than many of the leaks discussed during College meetings. The leaks identified here happened a point in time where policy change was still possible. Quite a number of stakeholders had also received more than one leaked version of 
the draft; they were thus able to monitor if and how their proposed changes were included by the Commission services. In the case of the CFP reform, the change was actually very substantial between the first draft and the final proposal adopted, both in favour of national fisheries interests and in favour of general environmental interests, the two key dimensions of bureaucratic politics in this case (Patz 2014). This gives support to Conjecture 2 that leaking is done strategically to influence bureaucratic politics, even though the data gathered in this survey cannot trace this in detail (e.g. establish which departments leaked to which stakeholders).

In summary, leaks are a regular topic at the highest level, especially when leaks "undermined the principle of collective responsibility and the confidentiality of the Commission's deliberations" (European Commission 2014: 20) and required "communication efforts [...] in order to convey the right message" (European Commission 2010a: 27). However, the survey with leak recipients indicates that leaking can happen several times during regular administrative decision-making inside the Commission. Those leaks reach a wide range of outside sources, from interest groups to the press, even those without direct access to the Commission. This suggests that high-level complaints about leaks and requests to the "Secretary-General [...] to review these problems and to propose improvements in working methods and investigations to establish how these documents were leaked" (Euroepan Commission 2012c: 16) are not effective.

In the following section, I discuss what these measures are and to what degree leaking is actually prevented in the Commission.

\section{The politics of leak prevention in the European Commission}

In reaction to the early-day leaks of the new Juncker Commission, the Commission president introduced "particularly stringent methods ... used to guarantee the confidentiality" in early 2015 when preparing the Commission's Communication on the Stability and Growth Pact (European Commission 2015a: 25), However, there was

"general regret [in the College of Commissioners] that the measures taken to ensure the confidentiality of this complex and sensitive draft communication had resulted in the Members of the Commission and their Chefs de cabinet being given insufficient time, in their view, to examine the proposal." (European Commission 2015a: 21) 
This small story seems typical for the argument that the literature on leaking as bureaucratic politics has been making. On one side, administrative leaders are unhappy about leaking. The measures they propose are rather of a social nature, in the case above meaning the shorting of consultation times. However, when these measures are addressed to the most likely leakers at the top, this same group of people is unhappy of having their political participation rights curtailed. When, in September 2016, the directors-general of the Commission discussed an 'anti-leak strategy' seemingly directed at the general staff of the Commission, the idea to increase control over EU officials was met with resistance from staff unions that did not want a culture of control and supervision (EurActiv 2016). The idea was subsequently scrapped, keeping the framework of rules and measure already in place to prevent leaking.

The evidence presented in this section shows how the European Commission has been addressing the risk of leaks through these administrative rules and political measures. I argue that even though leaks are regularly discussed at highest levels and detailed rules and technical measures exist to prevent leaking, the follow up through sanctions or change of political practices seem limited (cf. Conjecture 3.1+3.2). Instead, the qualitative data available suggests that leak prevention happens in selected instances, especially where the Commission leadership attempts to keep control over timing. This builds on previous research that has already shown how EU institutions try to prevent that classified EU information is published (for an overview see Curtin 2014; Galloway 2014). It also adds to recent contributions on secrecy and the "space to think" and on how they are constructed in EU institutions like the Council of the European Union and the European Council. These discussions underline that secrecy and confidentiality do not only cover information that is classified in the narrow sense but also so-called "sensitive unclassified information"2 (Hillebrandt and Novak 2016).

However, the protection of confidentiality has been an established rule at EU-level for a long time. EU officials have been bound by the obligation not to leak information and documents since the first EU staff regulations. The key rule has remained, in substance, almost the same over the past 55 years:

1962 version: "An official shall exercise the greatest discretion with regard to all facts and information coming to his knowledge in the course of or in connection with the performance of his duties; he shall not disclose to any unauthorised person any

\footnotetext{
${ }^{2}$ In the European Commission this type of information is referred to similarly as "sensitive non-classified information" (European Commission 2015b).
} 
document or information, in any manner whatsoever, not already made public." (Original EU Staff Regulation 1962, §17, first sentence)

2017 version: "An official shall refrain from any unauthorised disclosure of information received in the line of duty, unless that information has already been made public or is accessible to the public." (current version of the EU Staff Regulations, §17, first sentence, as amended in 2004)

In the absence of fundamental changes in the legal basis against leaking by EU officials, the question is whether technological changes or the megaleaks in recent years have led to a change in implementing rules, in administrative policy or in other measures that would result in limiting leaking. Through a freedom of information request made to the Commission based on Regulation 1049/2001, all current internal rules and guidelines pertaining to the $\S 17$ of the Staff Regulations, including any versions in place during the past decade, were requested.

\begin{tabular}{|c|c|}
\hline pr & \\
\hline $\begin{array}{l}\text { on "Security in the Commissic } \\
\text { Article } 9 \text { on "Security me } \\
\text { information" }\end{array}$ & \multirow{5}{*}{$\begin{array}{l}\text { Commission Decision 2001/844 of } \\
29 \text { November } 2001 \text { amending its } \\
\text { internal Rules of Procedure, in } \\
\text { particular adding an annex with } \\
\text { "Rules on Security" that contained } \\
\text { detailed rules on the handling of } \\
\text { classified information } \\
\text { Commission Decision } 2005 / 94 \text { of } 3 \\
\text { February 2005 amending Decision } \\
2001 / 844 \text {, adapting the annex after } \\
\text { EU enlargement and after the } 2003 \\
\text { agreement between EU and NATO } \\
\text { on the security of information } \\
\text { Commission Decision } 2006 / 548 \text { of } 2 \\
\text { August 2006 amending Decision } \\
\text { 2001/844, adapting the annex to } \\
\text { include rules for how to interact with } \\
\text { contractors involved in matters } \\
\text { related to EU classified information }\end{array}$} \\
\hline & \\
\hline & \\
\hline & \\
\hline & \\
\hline
\end{tabular}

Table 2. Full set of rules and guidelines of the Commission pertaining to \$17, EU Staff Regulations, received from DG HR.E.3, the Unit for "Ethics \& Ombudsman" of the Commission in February 2017.

Most of the rules and procedures covered in Table, including the previous versions, relate to the technical and general protection of classified information. The changes made and some of the more technical guidelines take into account technological advances (Conjecture 3.2), but rather with regard to matters of involuntary disclosure than to voluntary leaking. There is very 
little reference in the rules and guidelines to matters that may be revealed in leaks that are more typical for leaking as part of bureaucratic politics, such as guidelines on how to handle early policy drafts. The "practical guide to Staff Ethics and conduct" covers a number of issues under its clarifications for $\S 17$ of the Staff Regulations that do not relate to classified information but rather to commercially sensitive information and personal data. This type of information is what Commission Decision 2015/443 calls "sensitive non-classified information" (Art. 9.5b). Where such sensitive non-classified information is concerned, it

"shall only be released to those individuals who have a 'need-to-know'. When deemed necessary for the effective protection of its confidentiality, it shall be identified by a security marking and corresponding handling instructions approved by the DirectorGeneral for Human Resources and Security" (Art. 9.6)

The lack of reference to confidentiality in typical political situations and the focus on security measures relating to classified information indicates little focus on regular leaks. To test this assumption, I requested the annual reports of the Commission's Investigation and Disciplinary Office (IDOC) for the past decade (2006-15) and analysed these for cases referring to leaks or unauthorised disclosure of documents. It is clear from Figure 2 below that there have been very few cases in which Commission staff has been sanctioned for leaking, clearly confirming Conjecture 3.1

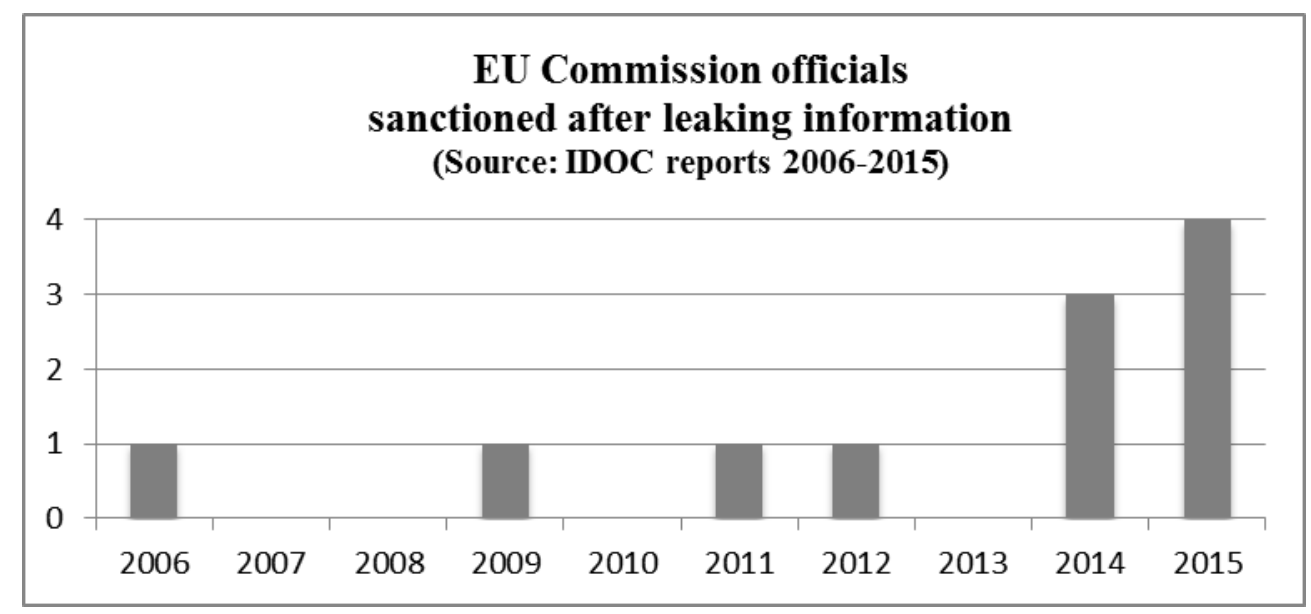

Figure 2. Number of Commission officials sanctioned per year. Own compilation based on IDOC Annual Reports.

While we do not know how many cases of leaking there have been in that period overall, the comparison with the number of times leaks have been on the College agenda (Figure 1) and the number of sanctions (Figure 2) is revealing. Whereas in 2012, leaking was on the Commission agenda seven times, there was only one sanction pronounced for a "seconded national expert who disclosed internal documents to the national authorities prior to their 
approval by the Commission" (IDOC 2012: 27) in 2012 and none in 2013. The 2006 and two of the 2014 cases relate to leaking of information during tender procedures, i.e. also not typical policy leaks. Only the 2009 case relates to leaking to a news organization, but it seemed to be flagged because the official concerned received a payment for providing this information (IDOC 2009: 8). Two of the cases of policy leaking to interest groups involved instances of undue influence, one official receiving favours in return (IDOC 2011: 6), one relating to an official who not only leaked information but also included the "industry stakeholder" comments into a policy draft without informing the hierarchy (IDOC 2015: 8). Thus, most of the cases where officials have been sanctioned related to leaking usually come with additional offences.

In the absence of sanctioning of leaks, the question is whether one can identify other means of leak prevention that relate, in particular, to the Commission leadership's strategic interests (Conjecture 4). Qualitative evidence from the Commission meeting minutes and from interviews with Commission officials on the development of the politically sensitive proposal for the EU's 2014-20 Multiannual Financial Framework (MFF) suggest two typical measures that are employed at the will of the Commission leadership (the president or individual Commissioners):

1. Time games: As we have already discussed above, the Commission leadership has used the timing of decision-making and the duration of internal consultation in order to prevent leaks. This included holding sensitive sessions of the weekly Chefs de Cabinets meetings where fines for member states were decided only short before the main Commission meeting so that the press and the state(s) concerned would only know about decisions after the College meeting (European Commission 2010b: 8); shorting consultation periods for the development of crucial policies (Commission 2015a); or delaying the start of interservice consultations until after a moment when leaks could get most media and member state attention (European Commission 2012b)

2. Creating restricted and trusted groups: For politically sensitive decision-making, there are indications that the Commission leadership creates groups that work differently than the regular internal decision-making with a lead department and subsequent interservice consultation. For example, when developing the recent MFF proposal, a closely knit group of officials from the DG Budget, the Commission Secretariat General and a few other officials was created. The fact that there was no leak was "in the Commission standard ... just extraordinary". This required "fantastic 
discipline ... because it's not only the technical measures [taken] to ensure the security of documents [...] but it is also the commitment of the people" (Interview Director General, 17 Oct 2014). Creating small groups linking the political level directly with a few key experts at the level of budget units communicating the most sensitive figures only via encrypted mail made it possible that "many of our colleagues never saw the figures until the end, when it came out" (Interview Head of Unit, 17 Oct 2014).

The exceptional circumstances under which these social measures for leak prevention are put in place - and the complaints from Commissioners and Commission officials when this happens - underlines that there is a limit to what the European Commission can do, and that working against the modus operandi of internal consultation requires specific legitimization (such as the political salience of a given process). As long as the Commission relies on wideranging internal consultation and has to take into account complex interests of its horizontally and vertically fragmented bureaucracy, of member states, of the European Parliament and the community of interest groups in developing new policy, preventing leaks comes at a cost that the Commission leadership does not seem willing to pay except in a few cases with quasicriminal implications or of highest political importance.

\section{Conclusion}

The present article has built on previous efforts to explain the dynamics of leaks and leak prevention efforts in the executives of Western democracies. The general trend observed elsewhere that leaks are frequent but that active leak prevention and sanctioning is selective can be confirmed for the European Commission. Whereas the Commission leadership is unhappy with leaks that specifically undermine its collective decision-making, it only seems to be able to detect a few cases and mostly pursues those cases where leaking comes in combination with other types of unethical or criminal behaviour. Instead of sanctioning leaks that have happened, the President and the Secretariat General as the link between the College and the rest of the bureaucracy seem to prefer ad hoc measures that limited internal consultation to a selected few officials or that adapt the timing of decision-making to control when leaks are most likely to happen. These findings contribute to the recent literature on the European Commission as a complex international public administration by showing how leaking as a phenomenon can drive the choice of ad-hoc internal decision-making procedures instead of relying on established routines. It also indicates that the Commission as a rule- 
based bureaucracy may not actually implement the rules that it gives itself, including those relating to confidentiality and secrecy - especially if pursuing every breach of these rules would undermine the leadership's own interests in controlling information flows.

With regard to the debates on secrecy in the EU and in Europe, the paper focuses attention to the empirical reality of leaks and anti-leak measures as a representation of the struggle between secrecy and publicness in modern democracy and public administration. The findings suggest that, in an environment with close contacts between public officials, interest groups and a free press, maintaining confidentially is impossible whenever there are opposing views within large public administrations such as the European Commission. The study of legal rules on confidentiality therefore has to be complemented with a better understanding of the effectiveness of these rules and the conditions under which they are actually enforced to protect or increase the veil of bureaucratic and diplomatic secrecy. 


\section{References}

Abazi, Vigjilenca (2015). Secrecy and oversight in the European Union: The law and practice of classified information. Doctoral Thesis (unpublished), University of Amsterdam.

Alaimo, Kara (2016). 'Which government officials leak unauthorized information to the press in Washington?', Journal of Public Affairs 16:1, 7-15.

Bovens, Mark A.P.; Geveke, Henk G.; de Vries, Jouke (1995). 'Open public administration in the Netherlands: the politics of leaking', International Review of Administrative Science 61, 17-40.

Christoph, James B. (1993). 'The Effects of Britons in Brussels: The European Community and the Culture of Whitehall', Goverance 6:4, 518-537.

Cini, Michelle (1997). The European Commission. Leadership, organisation and culture in the EU administration. Manchester: Manchester University Press.

Corporate Europe Observatory (2014). 'Leaked Draft Commission Work Programme 2015', 15 December 2014, available at: https://corporateeurope.org/powerlobbies/2014/12/leaked-draft-commission-work-programme-2015 (Accessed: 17 February 2017).

Curtin, Deirdre (2014). 'Overseeing Secrets in the EU: A Democratic Perspective', JCMS 52(3), 684-700.

De Jong, Jurgen; de Vries, Michiel (2007). 'Towards unlimited transparency? Morals and facts concerning leaking to the press by public officials in the Netherlands', Public Administration and Development 27:3, 215-225.

EU Staff Regulations (1962). 'Regulation No 31 (EEC), 11 (EAEC) laying down the Staff Regulations of Officials and the Conditions of Employment of Other Servants of the European Economic Community and the European Atomic Energy Community; OJ 1385/62. 14.6.62.

EU Staff Regulations (2017). Consolidated version of EU Staff Regulation (1962), Document 01962R0031-20170101, 1.1.2017.

EurActiv (2016). 'EU's “anti-leaks strategy" leaked', by Jorge Valero on 27 Sep 2016 (updated on 28 Sep 2016); available at: http://www.euractiv.com/section/tradesociety/news/eus-anti-leaks-strategy-leaked// (accessed: 15 February 2016). 
European Commission (2010a). 'Minutes of the 1919th meeting of the Commission', 26 May 2010. PV(2010)1919.

European Commissino (2010b). 'Minutes of the 1935th meeting of the Commission', 9 November 2010. PV(2010)1935.

European Commission (2012a). 'Minutes of the 2023rd meeting of the Commission', 14 November 2012. PV(2012)2023.

European Commission (2012b). Email sent by Catherine Day (SG) to Paola Testori Coggi (SANCO) under the subject line "Tobacco Products directive”, 23 September 2012; Ares(2013)295261, available at: https://www.asktheeu.org/en/request/393/response/1190/attach/5/Pauling\%202013\%20 1016\%20annex.pdf (Accessed: 24 February 2017).

European Commission (2012c). 'Minutes of the 1990th meeting of the Commission', 14 February 2012. PV(2012)1990.

European Commission (2014). 'Minutes of the 2110th meeting of the Commission', 16 December 2014. PV(2014)2110.

European Commission (2015a). 'Minutes of the 2111th meeting of the Commission', 13 January 2015. PV(2015)2111.

European Commission (2015b). 'Commission Decision (EU, Euratom) 2015/443 of 13 March 2015 on Security in the Commission', OJ L 72, 17.3.2015.

Flynn, Kathryn (2006). 'Covert Disclosures - Unauthorized leaking, public officials and the public sphere', Journalism Studies 7:2, 256-273.

Flynn, Kathryn (2011). 'The Practice and Politics of Leaking', Social Alternatives 30:1, 2428.

Galloway, David (2014). 'Classifying Secrets in the EU', JCMS 52:3, 668-683.

Goetz, Klaus H.; Patz, Ronny (2016). 'Pressured budgets and the European Commission: towards a more centralized EU budget administration?', Journal of European Public Policy 23:7, 1038-1056.

Hartlapp, Miriam; Metz, Julia; Rauh, Christian (2013). 'Linking Agenda Setting to Coordination Structures: Bureaucratic Politics inside the European Commission', Journal of European Integration 35:4, 425-441. 
Hillebrandt, Maarten; Novak, Stéphanie (2016). "'Integration without transparency"? Reliance on the space to think in the European Council and Council', Journal of European Integration 38:5, 527-540.

Howlett, Michael; Goetz, Klaus H. (2014). 'Introduction: time, temporality and timescape in administration and policy', International Review of Administrative Sciences 80:3, 477492.

Hustedt, Thurid; Seyfried, Markus (2016). 'Co-ordination across internal organizational boundaries: how the EU Commission co-ordinates climate policies', Journal of European Public Policy 23:6, 888-905.

Hermann, John (2017). 'The Media's Risky Love Affair With Leaks', New York Times Magazine, 6 February 2017, available at: https://www.nytimes.com/2017/02/06/magazine/the-medias-risky-love-affair-withleaks.html (Accessed: 11 February 2017).

Herrmann, Christoph (2015). 'Transleakancy', in: Herrmann, Christoph; Simma, Bruno; Streinz, Rudolf (eds.) Trade policy between law, diplomacy and scholarship. Liber amicorum in memoriam of Horst G. Krenzler, Cham et al.: Springer, 39-46.

Hood, Christopher (2010). 'Accountability and Transparency: Siamese Twins, Matching Parts, Awkward Couple?', West European Politics, 33:5, 989-1009.

Kassim, Hussein P.J.; Bauer, M.W.; Connolly, S.; Dehousse, R.,; Hooghe, L.; Thompson, A. (2013). The European Commission of the Twenty-First Century, Oxford: Oxford University Press.

Michael, Gabriel J. (2015). 'Who's Afraid of WikiLeaks? Missed Opportunities in Political Science Research; Review of Policy Research 32(2), 175-199.

Patz, Ronny (2014). Information flows in the context of EU policy-making: affiliation networks and the post-2012 reform of the EU's Common Fisheries Policy. Doctoral Thesis, University of Potsdam. Available at: https://publishup.unipotsdam.de/files/6824/patz_diss.pdf (Accessed: 26 February 2017)

Patz, Ronny (2016). 'Just the TTIP of the Iceberg? Dynamics and Effects of Information Leaks in EU Politics', European Journal of Risk Regulation 7:2, 242-246.

Pozen, David E. (2013). 'The Leaky Leviathan: Why the Government Condemns and Condones Unlawful Disclosures of Information', Harvard Law Review 127:2, 512-635. 
Prémon, Karine (2010). L'incidence des fuites non-autorisées sur la politique étrangère des États-Unis. Stratégie d'influence bureaucratique ou coup d'épée dans l'eau?, Doctoral Thesis, Université du Québec à Montreal, March 2010, available at: http://www.archipel.uqam.ca/2877/1/D1904.pdf (Accessed: 24 Feb 2017).

Prémon, Karine (2012). Les secrets de la Maison-Blanche: l'impact des fuites d'informations confidentielles sur la politique étrangère des États-Unis; Montreal: Presses de l’Université de Québec.

Reich, Zvi (2008). 'The Anatomy of Leaks. Tracing The Path of Unauthorised Disclosure in the Israeli Press', Journalism 9:5, 555-581.

Reich, Zvi; Barnoy, Aviv (2016). 'The Anatomy of Leaking in the Age of Megaleaks', Digital Journalism 4:7, 886-898.

Rosén, Guri (2015). 'EU Confidential: The European Parliament's Involvement in EU Security and Defence Policy'; JCMS 53:2, 383-398.

Spörer-Wagner, Doreen; Marcinkowski, Frank (2010). 'Is Talk Always Silver and Silence Golden?', Javnost - The Public 17:2, 5-26.

Willard Report (1982). 'Report of the Interdepartmental Group on Unauthorized Disclosures of Classified Information'; March 31, 1982, available at: https://fas.org/sgp/library/willard.pdf (Accessed: 25 February 2017).

Wille, Anchrit (2013). The Normalization of the European Commission: Politics and Bureaucracy in the EU Executive. Oxford: Oxford University Press. 